\title{
THE PROTECTION OF CREDITORS WITHIN INSOLVENCY CASE OF THE COMMERCIAL BANK
}

\author{
Janis Grasis*
}

\begin{abstract}
The aim of this article is to analyze the protection of creditors within insolvency case of the commercial banks. The research is based on the case study of the Latvian commercial banks, which have faced financial problems: AS "Rīgas komercbanka" and AS "Latvijas Krājbanka". Comparative analysis of both cases has been done. Comparative method and the method of the analysis of the legal norms are the two main methods used in this article. The research limits are case studies with insolvency cases of the commercial banks, but not in connection with the other legal persons. The main findings are that Latvian legal norms on insolvency protection of the rights of the creditors in full amount with one exception. The author has prepared proposal for amendment in the Latvian law "on credit institutions". The research and analysis are original, and the value of the article is prepared and formulated amendments to the Latvian Credit Institutions Law.
\end{abstract}

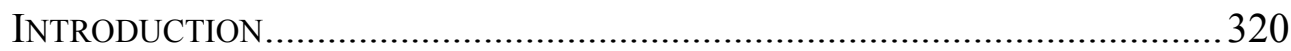

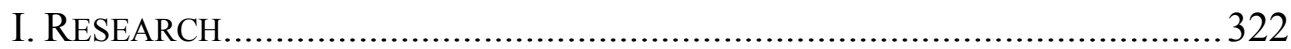

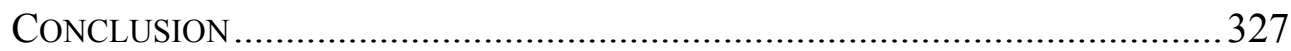

\section{INTRODUCTION}

The great international banking crisis that broke out in August 2007 is only the latest episode in a lengthy history of banking around the world. Failures of the banks have often been sudden-with depositors scrambling to withdraw their funds. All banking crises have been costly, both in direct cash costs to bank creditors and to the governments who have bailed them out, and indirectly in the associated spillover effects on economic activity

\footnotetext{
* A Doctor of international law, Associated Professor of the BA School of Business and Finance, also head of the Department of the Business and Business Informatics at the BA School of Business and Finance. He has a previous working experience both in public and private sector, including State Revenue Service, AS "Saules banka", AS "Rietumu Banka", AS Commercial bank "Baltikums Banka" etc. Since 2003 Janis Grasis is basicly connected with academic work at the BA School of Business and Finance. On the topic of the present article the author has made conference report in the International scientific conference "New business Solutions for Emerging Future" on April 25, 2013 at BA School of Business and Finance in Riga, Latvia. The author also participated as an associated expert in the court hearings of the Constitutional claim initiated by the creditors of AS "Latvijas Krajbanka" in the Constitutional court of the Republic of Latvia. Research fields: International Law, Banking Law, Taxation and Trusts.
} 
including that caused by reduced access to credit ${ }^{1}$. Also Latvian banking system faced the crises: factual insolvency of the "Parex bank" in 2008 and the problems with "Latvijas Krajbanka" in 2011.

The author agrees that the Latvian financial market and its regulation are comparatively young, as it started to develop in $1990^{2}$. At the beginning of the development, the regulation was so liberal that caused in the first banking crisis in 1994-1995 ${ }^{3}$. With the adoption of the new Credit Institutions Law in 1995, the situation with the legal regulation started to improve, especially when Latvia joined the European Union in 2004. But still new problems in the banking sector, especially case with Latvijas Krajbanka, indicated problems in the legal regulation of the insolvency of credit institutions and the protection of the creditors.

In general, according to the theory of the insolvency process, there are varying degrees of possible creditor involvement in decision-making in insolvency proceedings, based upon the functions it is determined should be performed by creditors. A determination as to which functions should be given to creditors involves a consideration of the overall design of the insolvency law and the balance to be achieved among the roles of the court, the insolvency representative, the debtor and creditors, in particular in terms of oversight and supervision. Creditor participation is increasingly regarded as an important element of an insolvency law, especially as a counterbalance to the roles assigned to other participants under the law and as an important means of safeguarding creditor interests. One approach allows creditors only a low level of participation. Under such insolvency laws, the insolvency representative is required to make all key decisions on uncontested general matters of administration, with creditors playing a marginal role and having little influence. Other approaches afford creditors greater participation in the proceedings. Such participation may range from participation at an initial meeting where certain matters are considered, to an ongoing role, which may require creditors to perform an advisory function or, at a higher level, to approve certain acts and decisions of the insolvency representative ${ }^{4}$.

\footnotetext{
${ }^{1}$ CAPrio G. (JR.) ANd Honohan P., BANKING Crises, the Oxford Handbook of Banking 673-692 (Oxford University Press 2010).

${ }^{2}$ Černoštana M., Investor Protection in Insolvent Credit Institutions under Latvian Law, 10(2)

EUROPEAN COMPANY LAW 38-45 (Wolters and Kluwer, June 2013).

${ }^{3}$ Vaidere I, Banku sistēmas attīstība Latvijā 1988-1997 (Riga 1999).

${ }^{4}$ UNCITRAL, LegisLATIVE GUIDE ON INSOLVENCY LAW (New York, United Nations).
} 


\section{RESEARCH}

If we look to the current Latvian legislation, it provides rather high participation of the creditors in the insolvency process. For example: according to Article 179, the decision on the implementation of restoration and the restoration plan shall come into effect after its approval by the Financial and Capital Market Commission and the meeting of creditors ${ }^{5}$. Similarly, according to the Article 181, the decision on the implementation of restoration, the restoration plan and subsequent decisions regarding amendments to such plan shall be approved by the Financial and Capital Market Commission within 15 days from the day of their submission and the administrator shall submit them for approval to the meeting of creditors ${ }^{6}$. An administrator may request the Financial and Capital Market Commission or the meeting of creditors to discontinue the restoration, if:

(1) restoration actions are not taking place in accordance with the restoration plan;

(2) the solvency of the credit institution has not improved to the extent anticipated in the time period specified in the restoration plan; or

(3) it is determined that the restoration plan cannot be executed (Article 183 of Credit Institutions Law).

In all the mentioned cases, the creditors play a significant role in the insolvency process of the credit institutions. But the next case is a special exception: A decision on initiation of bankruptcy proceedings shall be taken, upon receipt of a petition, by a court. A decision of an administrator on the submission of a petition to a court shall be approved by the Financial and Capital Market Commission, but without any consultations or acceptance of the creditors (Article 184 of Credit Institutions Law, 1995). This legal norm of the insolvency law influenced a lot of the insolvency cases of the Latvijas Krajbanka and was a reason to submit the constitutional claim to constitutional court by the creditors.

The constitutional complaint was submitted by the creditors of the insolvent joint stock company "Latvijas Krājbanka". They note that the contested norms deprive them of the right to decide upon issues related to their property, since by leaving the decision on implementation of the restoration procedure at the discretion of the administrator and the Financial and Capital Market Commission (FCMC), the creditors are not involved in the decision-making. Article 105 of the Satversme Constitution of Latvia stipulates, that:

\footnotetext{
${ }^{5}$ Credit Institutions Law, Latvian Law (1995).

${ }^{6}$ Ibid.
} 
Everyone has the right to own property. Property shall not be used contrary to the interests of the public. Property rights may be restricted only in accordance with law. Expropriation of property for public purposes shall be allowed only in exceptional cases on the basis of a specific law and in return for fair compensation $^{7}$ (Satversme, 1922).

On March 1, 2013, the Constitutional Court pronounced its judgement in Case No. 2012-07-01.

On Compliance of Article 179(1) of the Credit Institutions Law with Article 105 of the Satversme of the Republic of Latvia and Article 179 (2) of the Credit Institutions Law with the first sentence of Article 92 of the Satversme of the Republic of Latvia ${ }^{8}$.

The Constitutional Court assumed that Article 105 of the Satversme envisages comprehensive guarantees to property rights, including the right to claim in connection with meeting obligations, as well as the right to decide on property related issues. However, the Court also recognized that the owner assumes risks related to the use of his or her property. The State does not have the obligation to avert the loss of the property's value caused by market factors, as well as to assume responsibility for the credit institution's liabilities vis-à-vis its creditor' .

According to the judgement by The Constitutional Court, the solutions in cases of insolvent credit institutions are aimed at the protections of depositors. In the insolvency procedure of a credit institution, it is important, first of all, to ensure lawful and effective course of this procedure, by entrusting it to a professional and independent expert - the administrator, secondly, to ensure the stability of financial market by imposing certain duties and granting rights to the supervisor of the financial and capital market-FCMC. The Constitutional Court recognized that the procedure, in which the decision on implementing restoration is adopted and approved, balances the interests of the creditors and society, envisaging reciprocal supervision and influence of the involved institutions and creditors, as well as ensures that a restoration plan, which is unfeasible and threatens the stability of the financial system, is not adopted, and that the creditors' rights are not unfoundedly restricted. In addition, FCMC also participates in assessing the insolvency solution (both in the case of restoration and bankruptcy procedure). Moreover, without the creditors' consent restoration is impossible. Thus, the procedure for adopting and approving the decision

\footnotetext{
${ }^{7}$ Satversme (Constitution) of the Republic of Latvia (1922).

${ }^{8}$ The Judgement of the Latvian Constitutional Court of March 1, 2013 in the case No. 2012-07-01 (2013).

${ }^{9}$ Ibid.
} 
on applying restoration, balances the interests of society and the creditors, envisages reciprocal supervision and influence of the involved institutions and the creditors. The court controls the lawfulness of the bankruptcy procedure, thus ensuring balance between the interests of the creditors and society. Therefore the Constitutional Court recognized that the restriction to the fundamental right is proportional and Section 179(1) of the Credit Institution Law complies with Article 105 of the Satversme.

The Constitutional Court recognized also that the second contested norm (Article 179(2) of the Credit Institutions Law) was not applied in the insolvency procedure of the insolvent joint stock company "Latvijas Krājbanka", therefore it cannot infringe upon the fundamental rights of the submitters of the constitutional complaint. At the same time, the Court examined the applicants' statements that the "creditors have no right to appeal against the decision not to implement restoration". The Court found that, firstly, the Civil Procedure Law envisaged the right to appeal against any action by the administrator or lack thereof, secondly, several creditors of the insolvent joint stock company "Latvijas Krājbanka" had used this possibility in practice. Therefore, the Court recognized that the legal proceedings regarding the compliance of Article 179(2) of the Credit Institution Law with Article 92 of the Satversme should be discontinued.

The author agrees with the reasoning of the Constitutional Court, as they examined the issue from the narrow point of view whether the contested legal norms correspond to the Latvian Satversme (Constitution). But we have to look on this issue form the broader point of view. As indicated in the case proceedings the legal representative of the claimantssworn attorney E. Radzins, the financial corporation "Otkritije" has collected already 158 million of Latvian lats, missing 13 million in order to get 171 million Latvian lats, which was the minimum threshold in order to start the restoration of the Latvijas Krajbanka, established by the supervisor of the financial and capital market- $\mathrm{FCMC}^{10}$. It means that if the creditors can find 13 million Latvian lats or more, the restoration process could be started. Instead, the administrator, with the permission of the FCMC, submitted to the court petition to start bankruptcy procedure of the Latvijas Krajbanka. This is a bad financial management to start bankruptcy procedure without any consultation with the creditors. When the administrator was asked by judge how much time it takes to gather the meeting of the creditors, the answer was: one day. It means that from the

\footnotetext{
${ }^{10}$ Verbatim Report of the Proceedings of the Latvian Constitutional Court on January 22, 2013 in the case No. 2012-07-01 (2013).
} 
point of view of efficiency of the insolvency procedure, it does not take too much time to involve creditors in order to try to prevent the bank from bankruptcy as the last chance.

If we look back in the recent history of Latvian commercial banks, then insolvency case with AS "Rīgas komercbanka" in 1999 was totally different: In that case all interested persons, like State and the Bank of Latvia (Central bank), depositors and private creditors, including European Bank for Reconstruction and Development, took part in the restoration process of the bank. As a result AS "Rīgas komercbanka" was restored, and still operates in Latvian financial market under the new firm AS "DNB banka", and now belongs to the commercial bank from Norway.

AS "Rīgas Komercbanka" was declared insolvent on March 23, 1999 by Riga District Court. According to the decision of the court, it was obligatory for ten chairpersons of AS "Rīgas Komercbanka" to participate in the process of insolvency: President of the Bank Vladimirs Kuliks, Member of the Board and Chief accountant Marite Kurkulite, three vice presidents Tatjana Ratnikova, Irena Skobeleva and Andrejs Sergejevs, Chairman of the Supervisory Council Sols Bukingolts, Members of the Supervisory Council Aleksandrs Bondarevs, Karlis Cerbulis, Karina Izaksone and Georgs Krivickis.

Bank of Latvia under presidency of Mr. Einars Repse decided to support restoration process of the insolvent AS "Rìgas Komercbanka" on August 4, 1999. New commercial company_-"Rīgas Komercbankas rehabilitācijas aǵentūra LLC" was established by decision of the Bank of Latvia $^{11}$, and Bank of Latvia invested 15,546,000 Latvian lats of the public money in this company. According to the Article 14 of the law "On Bank of Latvia" "12, it was prohibited for Bank of Latvia to acquire shares of the AS "Rīgas Komercbanka" directly, but law allowed to establish own companies in order to ensure financial stability of the banking system (On Bank of Latvia, 1992).

The biggest shareholder of the bank-European Bank for Reconstruction and Development (EBRD) - also decided to grant more financial means in order to restart banking operations by AS "Rīgas Komercbanka" as soon as possible. The same similar steps were made by the agents of the syndicate creditors "Fuji Bank" and "Landesbank Schleswig-Holstein" by expressing willingness to help in restoration process of the bank, and offered concrete scheme for this. Capitalisation of the creditors claims was the main method used for restoration process of AS

\footnotetext{
${ }^{11}$ Decison of the Bank of Latvia No. 59/2 (1999).

12 On Bank of Latvia, Latvian Law (1992).
} 
"Rīgas Komercbanka". For example, the main producer of electricity in Latvia, state owned company AS "Latvenergo" had deposits in total amount of 54,789,349 Latvian lats within AS "Rīgas Komercbanka". It was calculated that in case of bankruptcy of AS "Rìgas Komercbanka", AS "Latvenergo" will recover only 5\%-10\% from the mentioned amounts in deposits; in case of the successful restoration process, if $50 \%$ of the deposits will be capitalized, AS "Latvenergo" will recover $50 \%$ of the total amount of deposits within eight months from restarting of banking activities by AS "Rīgas Komercbanka". Therefore Latvian Privatization Agency agreed to allow for AS "Latvenergo" to participate in the restoration process of the AS "Rīgas Komercbanka"13 (Instruction of the Latvian Privatization Agency, 1999).

According to the restoration plan, the managing director A. Šteinbergs of "Rīgas Komercbankas rehabilitācijas aǵentūra LLC" acquired 93,781,818 shares (totally $37 \%$ from share capital) of insolvent AS "Rìgas Komercbanka" in the nominal value 0.01 Latvian lats with total amount of 15,474,000 Latvian lats on August 13, 1999. In accordance with decision of the Bank of Latvia later, all the mentioned shares were sold to "Norddeutsche Landesbank Girozentrale" (NORD/LB) for 2,767,383 Latvian lats on May 18, 2000. The total direct losses for Bank of Latvia and its formed "Rīgas Komercbankas rehabilitācijas aǵentūra LLC" was 12,778,617 Latvian lats, as margin of acquiring price and price for selling shares of AS "Rigas Komercbanka". This was the price for restoration of the AS "Rigas Komercbanka" in order to ensure financial stability of the Latvian banking system.

Comparision of Two Insolvency Cases of the Latvian Commercial Banks

\begin{tabular}{|l|l|l|}
\hline & AS "Rīgas Komercbanka" & AS "Latvijas Krajbanka" \\
\hline $\begin{array}{l}\text { Willingness to start } \\
\text { restoration process }\end{array}$ & $\begin{array}{l}\text { By all interested persons, including } \\
\text { state, central bank, administrator, } \\
\text { creditors etc. }\end{array}$ & $\begin{array}{l}\text { Creditors were interested; I am not } \\
\text { sure about administrator and the state }\end{array}$ \\
\hline $\begin{array}{l}\text { Used solutions of the } \\
\text { insolvency }\end{array}$ & Restoration & Bankruptcy \\
\hline $\begin{array}{l}\text { Methods used for } \\
\text { insolvency solutions }\end{array}$ & Capitalisation of the creditors claims & Selling of the assets \\
\hline
\end{tabular}

The legal part of the restoration process of the AS "Rìgas Komercbanka" was finished by acceptance of the Latvian Government to sign package of four agreements (Intercreditor and Trust Deed, Pro-Forma Letter of Entitlement, The Shareholders Agreement and Debt Restructuring

\footnotetext{
${ }^{13}$ Instruction of the Latvian Privatization Agency No.167-1631 "On permission for state stock company 'Latvenergo' to participate in restoration of the insolvent stock company”, Rìgas Komercbanka (1999).
} 
Agreement) by Mr. J. Brazovskis on behalf of Latvian government (Instruction of the Cabinet of Ministers, 1999) ${ }^{14}$.

\section{CONCLUSION}

Taking into account the previous research, the author proposes the following amendment for Section (2) of the Article 184 of the Latvian law "On credit institutions": "A decision of an administrator on the submission of a petition to a court shall be approved by the Financial and Capital Market Commission after consultation with the meeting of creditors". In this case the rights of creditors are better protected, and it could reduce the new cases, when commercial banks are declared bankrupt. Restoration of the bank solvency is always better than a new bankruptcy case for the whole financial sector.

\footnotetext{
${ }^{14}$ Instruction of the Cabinet of Ministers of the Republic of Latvia No.399 "On power of attorney to sign documents in connection with the restoration process of the AS", Rigas Komercbanka (1999).
} 